See discussions, stats, and author profiles for this publication at: https://www.researchgate.net/publication/326591197

Territorial distribution of highly educated individuals in Hungary after 1990

Article in Regional Statistics · January 2017

DOI: 10.15196/RS070209

Some of the authors of this publication are also working on these related projects:

Related variety project View project 


\section{Territorial distribution of highly educated individuals in Hungary after 1990}

Izabella Szakálné Knowledge-intensive activities, such as business

Kanó services are nowadays more and more concentrat-

Faculty of Economics and ed in big cities or city regions. These activities re-

Business Administration, quire skilled labour, so young graduates in particu-

University of Szeged lar are present in these areas, while in rural areas

E-mail: labour force is less qualified. The study investi-

kano.izabella@eco.u-szeged.hu

Éva Kazemi-Sánta

Faculty of Economics and

Business Administration,

University of Szeged

E-mail:

santa.eva16@yahoo.de

Imre Lengyel

Faculty of Economics and

Business Administration,

University of Szeged

E-mail:

ilengyel@eco.u-szeged.hu gates whether this concentration phenomenon can be observed in Hungary, or rather regional equalization takes place. The authors analyse the spatial distribution of the population's educational level, in particular the spatial distribution of graduates. Their investigation is based on the 1990, 2001 and 2011 censuses of settlement level. The study analyses the evolvement of education and its impact on regional inequalities at different regional levels (settlement, micro-regional and county levels) by using basic statistical and concentration indices.

Keywords:

territorial distribution, educational level, regional inequalities

\section{Introduction}

Today, the economic growth and development of regions primarily depend on the quality of the human capital available, which is an important resource, particularly in the case of knowledge-intensive activities (Pike-Rodrígues-Pose-Tomaney 2006, Stimson-Stough-Nijkamp 2011, Todaro-Smith 2012). Knowledge-intensive activities operate efficiently mostly in a spatially concentrated manner. They are inexpensive and reliable if the number of both innovative firms and the related institutions and their employees reach a critical mass in a particular industry/business in the

Regional Statistics, Vol. 7. No. 2. 2017: 171-189; DOI: 10.15196/RS070209 
region (city), where they have agglomeration externalities (Capello 2015, Dicken 2015, McCann 2013).

The quality of human capital is assessed using various methods; the simplest method is with education level, or with the number of years spent in training. Teperics et al. (2016) examined the territorial characteristics of four dimensions of learning in order to map learning regions in Hungary in 2011. One of the four dimensions was formal learning, which can be measured by the educational levels reached. They found that its index is in a significant positive relationship with personal income tax per capita, and in a significant negative relationship with the unemployment rate on settlement level. The education level is not only important in terms of the economic growth of regions, but it also strongly influences an individual's situation and well-being. A higher level of education can entail lifestyle, health, and cultural advantages, in addition to more favourable job opportunities (TodaroSmith 2012). Researchers use different educational levels of the population as explanatory variables in the models of economic growth (Benos-Zotou 2014), sharing economy (Dudás et al. 2017) and international labour-mobility (Kincses 2015). Eurostat reports educational attainment as an indicator of urbanization (Brandmueller et al 2017).

In Hungary, following the regime change of 1990 and the transition to a market economy, new territorial processes can be observed (Barta et al. 2005, Dusek et al. 2014, Gál 2016, Lengyel 2004, Lengyel-Leydesdorff 2011, Róbert 1991, Sánta et al. 2015, Timár 2007). Adapting to the new challenges, the education level of the population considerably improved (Rechnitzer-Smahó 2006). Kiss, Tagai, and Thelbisz (2008) analysed spatial distribution of the population with certain educational levels based on census data between 1930 and 2001. They found that territorial disparities decreased along this period, although this process was slowing down.

In the socialist period before the regime change, from 1970 to 1988 , the number of students in tertiary education barely changed, fluctuating between 90,000 and 110,000 persons, where two-thirds were full-time students (see Figure 1). In this period, 20,000-25,000 students obtained university degree annually, $50-60 \%$ of them as full-time students. After 1990, the number of students increased sharply, due to an increase in the number of students with general certificate of secondary education as a requirement for tertiary education on the one hand, while university capacities considerably increased on the other hand. From 2000, 50,000-55,000 persons gain university degree annually, where the rate of graduated full-time students reaches $70 \%$.

The rate of highly educated individuals increased from $10.1 \%$ in 1990 to $18.0 \%$ in 2011, when it almost doubled. Despite a substantial increase in the number of newly graduated students, this rate was far below the 28 member states in the European Union (EU28) average of $23.7 \%$ in 2011; Hungary is at the $21^{\text {st }}$ position amongst the EU28. The rate of secondary school graduates increased from 28.7 to

Regional Statistics, Vol. 7. No. 2. 2017: 171-189; DOI: 10.15196/RS070209 
$49.0 \%$, while the rate with no grades of primary school decreased from 1.2 to $0.6 \%$.

Change in the number of undergraduate and graduate students in the Hungarian higher education

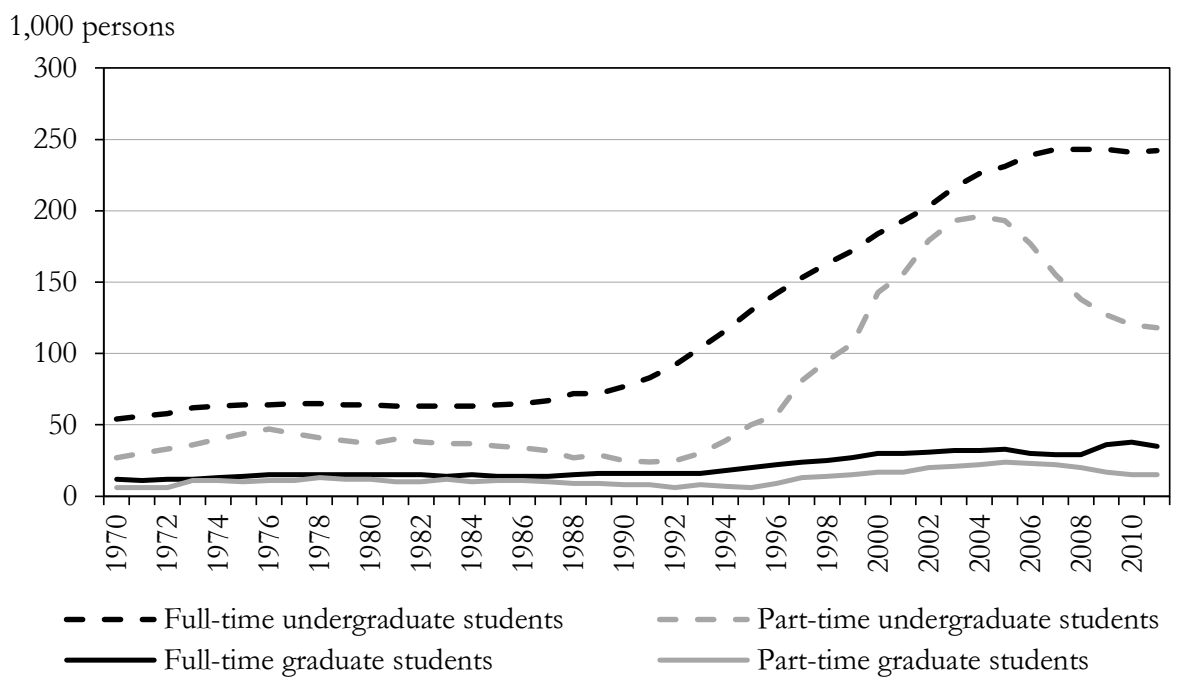

Source: Hungarian Central Statistical Office, STADAT Table 2.6.

The development of the Hungarian higher education after the regime change can be divided into three stages (Kozma-Tőzsér 2016). In the first stage of 1988-1993, several new higher educational institutions were established, mainly foundation and religious colleges. There was a quantitative explosion in the second stage of 1994-2004, where public higher educational institutions substantially increased the number of students, particularly in part-time programmes. In the third stage starting from 2004, the growth slowed down and stalled. Primarily, the number of part-time and graduate students declined in this stage.

The basic research question is: how did the rise in the education level, particularly in tertiary education, affect territorial differences? Did they continue to decrease or increase in the past two decades? Did it result in spatial concentration or territorial levelling? Did these processes take place in a similar manner at each territorial level?

Our paper aims to analyse the education level of the population, in particular the rate and spatial location of highly educated individuals, as well as the development of related territorial differences after 1990. We focus on tertiary education on the score of the fact, that a higher education level presumes all the education levels below.

Regional Statistics, Vol. 7. No. 2. 2017: 171-189; DOI: 10.15196/RS070209 
First, we describe the data collection process and the applied methodology, and then we present the specificities of the change of education level by settlement (LAU 2) and by the type of settlement. Following this, we analyse the tendency of territorial differences in the tertiary education of the population at subregional (LAU 1) and county (NUTS 3) levels.

\section{Data collection and methodology}

In Hungary, only the census provides exact settlement data for analysing the education level of the population, thus we used the data of the last three censuses (1990, 2001, and 2011) (HCSO 1993, 2003, 2013). We completed our research on various spatial division levels; we aggregated our LAU 2 data on LAU 1, NUTS 3, and regional (NUTS 2) territorial levels. In order to compare the three dates, we uniformly applied the settlement structure of 2011, thus in the case of settlement unions and separations over the studied period, we distributed our data in proportion to the population, and aggregated it. We calculated 3,176 settlements in total, where 23 districts of Budapest, which is the capital, are included in the database separately.

We can apply different indices to analyse territorial differences according to the education level of the population (Dusek-Kotosz 2016, Fischer-Getis 2010). In the calculation of the rates on which the analysis is based, we compared the highest completed level to the corresponding age group and we relied on the documents of the Hungarian Central Statistical Office for constraints and concepts (HCSO 2011).

In our analysis, we applied the following types of completed educational levels:

- population with no grades of primary school (their rate in the population over the age of 10),

- population with completed primary school (their rate in the population over the age of 15),

- population with completed secondary school, or vocational or apprentice school (their rate in the population over the age of 18),

- population with tertiary education (college or university) (their rate in the population over the age of 25).

We applied the following indicators/indices to calculate the development of territorial differences, focusing on different aspects (Nemes Nagy 2005, 2009, DusekKotosz 2016, Fischer-Nijkamp 2014):

- weighted coefficient of variation:

$$
V=\left[\frac{1}{\bar{y}} \sqrt{\frac{\sum\left(y_{i}-\bar{y}\right)^{2} f_{i}}{\sum f_{i}}}\right] * 100,
$$

where $y_{i}$ stands for the rate of a particular education level in the $i^{\text {th }}$ settlement, $\bar{y}$ denotes the rate of a particular education level nationally, and $f_{i}$ indicates the population of the $\dot{i}^{\text {th }}$ settlement in a particular age group.

Regional Statistics, Vol. 7. No. 2. 2017: 171-189; DOI: 10.15196/RS070209 
- Hoover index (index of dissimilarity):

$$
h=\frac{\sum_{i=1}^{n}\left|x_{i}-q_{i}\right|}{2}
$$

where $x_{i}$ and $q_{i}$ are distribution coefficients, $x_{i}$ specifies the rate of a particular education level in the $i^{\text {th }}$ settlement, within the national education level in question, and $q_{i}$ is the rate of the population of a particular age group in the $i^{\text {th }}$ settlement within the national value.

The Hoover index shows the percentage of people with a degree which should be transferred between territorial units so that their territorial distribution is equal to the distribution of the population in the age group in question.

- Gini coefficient (Gini index):

$$
G=\frac{1}{2 \bar{x}\left(\sum_{i} f_{i}\right)^{2}} \sum_{i} \sum_{j} f_{i} f_{j}\left|x_{i}-x_{j}\right|,
$$

where $x_{i}$ denotes the rate of highly educated individuals in the $i^{\text {th }}$ settlement, $\bar{X}$ indicates the rate of highly educated individuals at national level, and $f_{i}$ stands for the population of a particular age group in the $i^{\text {th }}$ settlement.

The Gini index is also an index of dissimilarity; it compares the average deviation of the rate of every observation unit from all other units to the average. In other words, it measures the size of the area bounded by the Lorenz curve and square diagonal. It describes the relative extent of the concentration.

\section{Education level of the population based on settlement data}

Based on the census data, the rate of population in the corresponding age group, with no grades of primary school declined from 1.2 to $0.6 \%$ from 1990 to 2011 (see Table 1). The rate of the population completing at least 8 grades of primary school increased from 78.1 to $95.1 \%$ by 2011 , which is a fairly high value. These two phenomena were enforced by the fact that the rate of non-educated individuals was the highest among older people, which means that demographic changes such as mortality reduced the no grades rate and enhanced the proportion of population with at least 8 completed grades of primary school. The rate of the population completing secondary school increased from 28.7 to $49.0 \%$. As such, approximately half of the population has a certificate. The rate of the population completing tertiary education also increased substantially; it reached $19 \%$ by 2011 . This is a high proportion, but it is below the average of the EU (announced by the Eurostat for the ages of 25-64): the EU average is $22.4 \%$, while it is $21 \%$ in Hungary in this age group. The question is: How did the national processes affect territorial differences?

Regional Statistics, Vol. 7. No. 2. 2017: 171-189; DOI: 10.15196/RS070209 
Table 1

Population having achieved a certain level of educational attainment as percentage of the corresponding age group

\begin{tabular}{l|c|c|c}
\hline \multicolumn{1}{c|}{ Level of educational attainment } & 1990 & 2001 & 2011 \\
\hline No grades of primary school & 1.2 & 0.7 & 0.6 \\
8 grades of primary school & 78.1 & 88.8 & 95.1 \\
Secondary school & 28.7 & 38.2 & 49.0 \\
College/university & 10.1 & 12.6 & 19.0
\end{tabular}

Note: The table shows cumulative education level figures assuming that a respondent in a category further down the table will have an equivalent education to all the categories above.

Source: Own calculation based on HCSO census data.

The indices of territorial dissimilarities calculated on the basis of the settlement data of the population with the highest education level are as follows (see Table 2):

- Weighted coefficient of variation: In terms of settlements, the variation of the education level decreased, except for the no grades of primary school, whose rate became minimal (see Table 1), in line with the national trend. The variation of 8 grades of primary school significantly decreased as elementary education was almost fully provided, while the rate of population completing primary school increased from 78.1 to $95.1 \%$. Although to a smaller extent, the variation of secondary school and university graduates by settlement decreased, and the latter can still be considered significant.

- Hoover index: The values of this index calculated on the different levels of education show a continuous decline, but significant differences can still be found, particularly in the case of people with university/college degree. $28.1 \%$ in $1990,27.1 \%$ in 2001 , while only $23.9 \%$ of the highly educated individuals should have been transferred between settlements to equal the education level distribution to the territorial distribution of the population over the age of 25 .

- Gini index: The values of the index indicate that in the case of the population with different education levels, the settlement differences decreased by 2001 in comparison to 1990 and then they further declined in 2011, although to a smaller extent. Compared to 2001, a major decrease can be observed in the case of secondary school and tertiary education in 2011. Thus, the relative extent of concentration decreases, which also implies a territorial levelling process of the education level.

In the case of all the three indices of dissimilarity, settlement differences measured on the basis of the highest completed education level decreased, except for the otherwise small number of people completing no grades of primary school. The specific differences between settlements decreased dynamically in the case of 8 grades of primary school and secondary school, while they declined more moderately in the case of tertiary education, where a certain levelling tendency is outlined

Regional Statistics, Vol. 7. No. 2. 2017: 171-189; DOI: 10.15196/RS070209 
for settlements in terms of the highest education level of the population. The competitiveness of the economy of settlements and regions is primarily influenced by qualified human capital; therefore, we provide a more detailed analysis on the territorial distribution of the settlement of highly educated individuals and its tendencies.

Table 2

Three dissimilarity indices by level of educational attainment

\begin{tabular}{l|r|r|r}
\hline \multicolumn{1}{c|}{ Dissimilarity index } & 1990 & 2001 & 2011 \\
\hline Weighted coefficient of variation (\%) & 106.6 & 138.5 & 146.1 \\
No grades of primary school & 12.0 & 8.1 & 3.7 \\
8 grades of primary school & 47.7 & 41.7 & 33.5 \\
Secondary school & 72.4 & 69.0 & 59.7 \\
College/university & & & \\
Hoover index & 29.4 & 32.1 & 30.1 \\
No grades of primary school & 5.1 & 2.8 & 1.4 \\
8 grades of primary school & 20.4 & 17.9 & 14.3 \\
Secondary school & 28.1 & 27.1 & 23.9 \\
College/university & & & \\
Gini index & 0.40 & 0.44 & 0.42 \\
No grades of primary school & 0.07 & 0.04 & 0.02 \\
8 grades of primary school & 0.27 & 0.24 & 0.19 \\
Secondary school & 0.38 & 0.37 & 0.33 \\
College/university & & &
\end{tabular}

Source: Own calculation based on HCSO census data.

\section{Spatial distribution of highly educated individuals}

In 2011, the rate of highly educated individuals was related to the size and spatial location of settlements (see Figure 2). Budapest and its agglomeration, as well as the county seats with larger universities, stand out in all three points of time. The provincial university towns, which are also region centres, function as an 'island'; the rate of people with university/college degree is much lower in the areas around these larger towns. Similarly, the regions of small villages having a labour force with a low level of tertiary education, and the regions along the southern and eastern borders are spatially separated.

Regional Statistics, Vol. 7. No. 2. 2017: 171-189; DOI: 10.15196/RS070209 
Rate of highly educated individuals in the total population,

Figure 2 by settlement, 2011

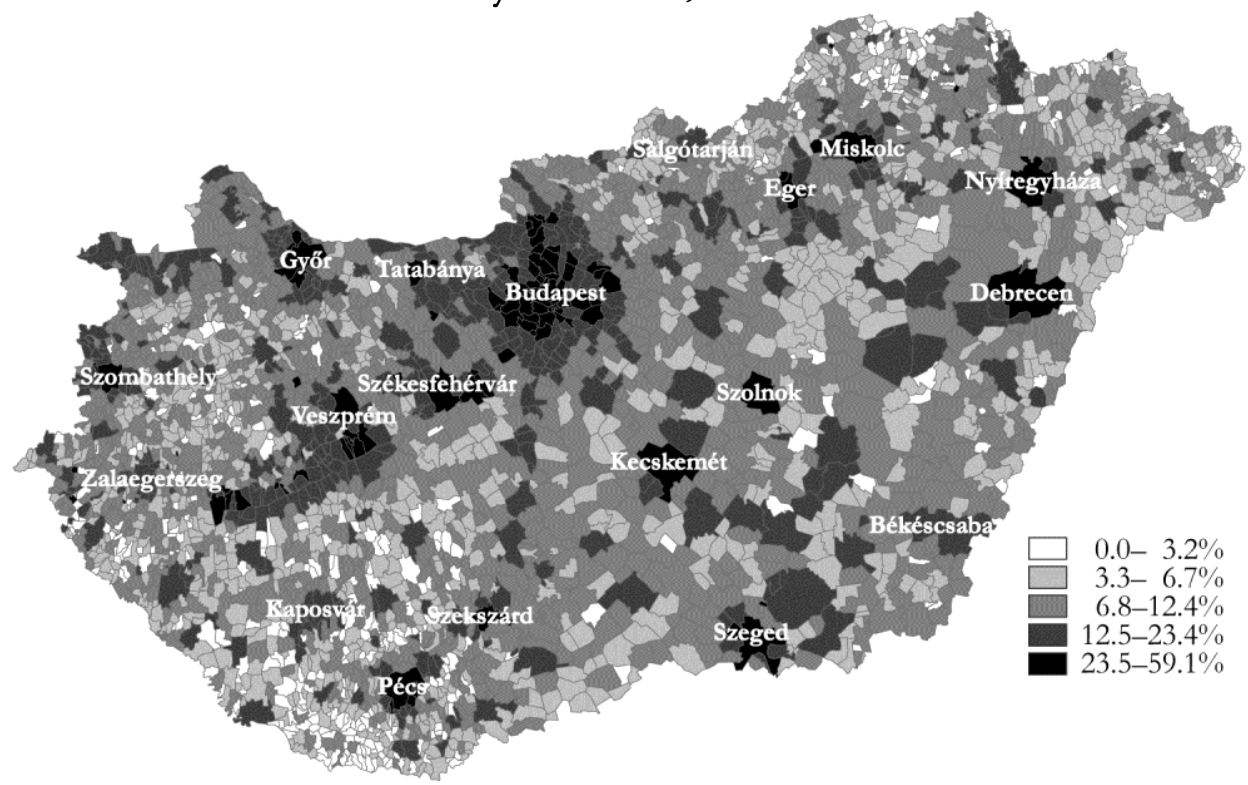

Source: Own elaboration based on HCSO census data.

Between 2001 and 2011, the rate of people with university/college degree increased in Budapest and its agglomeration to the greatest extent, the increase exceeds even the 35 percentage points in several places (see Figure 3). This rate also increased, to a smaller extent, between 7-10 percentage points in the county seats with larger universities. The rate of tertiary education increased to a smaller degree in two thirds of the settlements, particularly in smaller ones. The effect of motorways is noticeable; improving accessibility and mobility became important in many higher educational professions, and this is presumably the reason why the settlements alongside motorways have a more qualified population. There are also larger contiguous rural regions, internal peripheries characterised by a slow change. 
Figure 3

Change in the rate of highly educated individuals in the total population, by settlement, 2001-2011

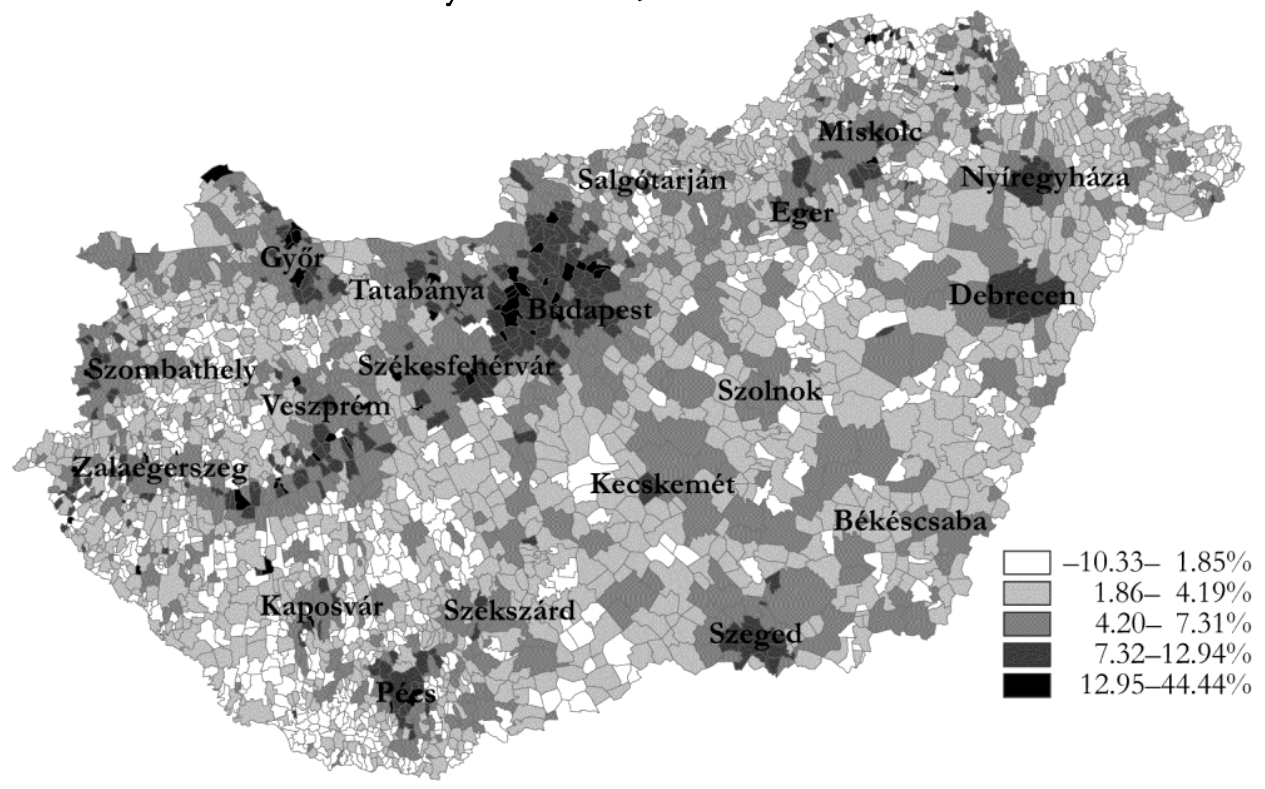

Source: Own elaboration based on HCSO census data.

In line with the Gini index, the Lorenz curves calculated on the distribution of highly educated individuals (for the data, see Table 1) also indicate a levelling process, even if it is only of a low degree (see Figure 4). On the basis of the curve, it can be established that settlement differences decreased by 2001 in comparison to 1990, and then continued to decline in 2011, although the change became slower.

All the described indices of dissimilarity indicate that the settlement differences of highly educated individuals decreased over the last period. The question arises whether the basic types of settlement are also characterised by this levelling process.

Regional Statistics, Vol. 7. No. 2. 2017: 171-189; DOI: 10.15196/RS070209 
Figure 4

Lorenz curves of highly educated individuals, based on settlement data

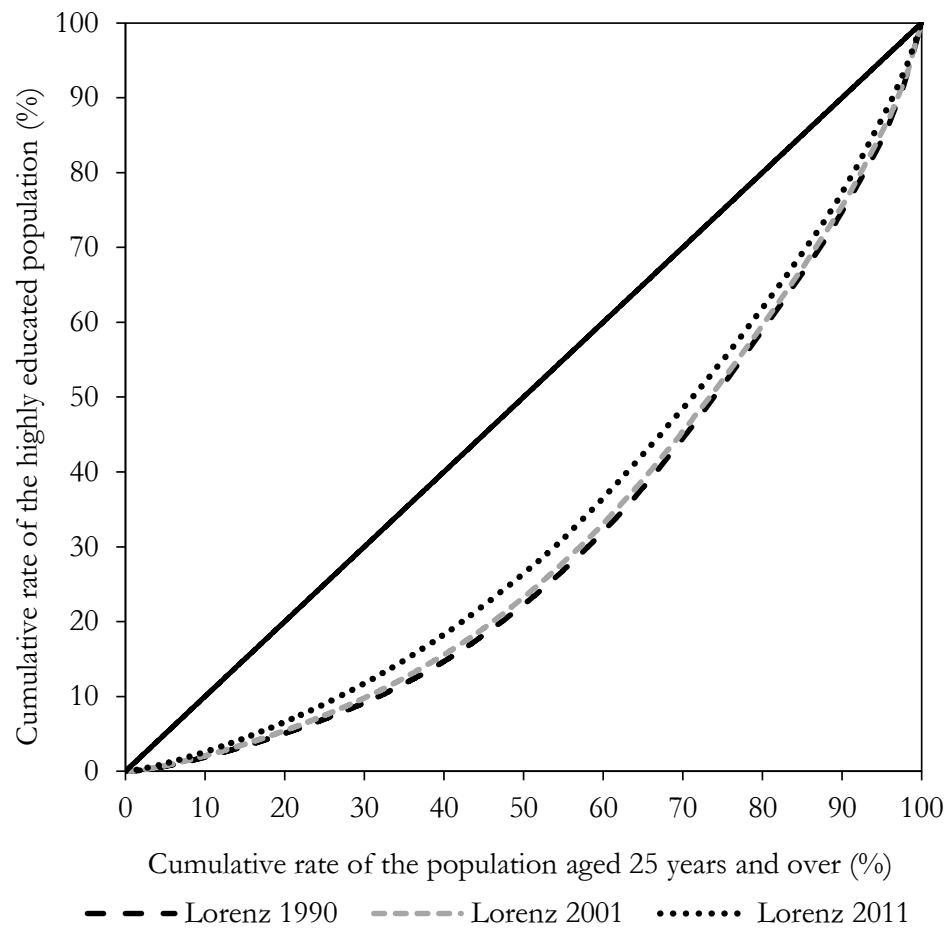

Source: Own elaboration.

We classify the settlements into four types: the capital, towns of county rights (there are 23 such in Hungary), the other towns, and villages (see Table 3). As shown, the number of people with degrees increased by about one and a half times in each type. The greatest extent of growth is in the villages, where it almost doubled, but considering its rate, it is still only half $(7.9 \%)$ of the national average $(15.5 \%)$. The high rate of the capital characterises both points of time; it is approximately double the national average, which also indicates that approximately one third of the Hungarian university/college graduates worked in the capital in 2011. There is a decrease in differences among the types, although it can be clearly observed that the rate of population completing tertiary education increased moderately in towns of county right.

Regional Statistics, Vol. 7. No. 2. 2017: 171-189; DOI: 10.15196/RS070209 
Table 3

Number of highly educated individuals aged 7 and over and their rate in the total population, by settlement type

\begin{tabular}{|c|c|c|c|c|c|}
\hline \multirow[t]{2}{*}{ Settlement type } & \multicolumn{2}{|c|}{$\begin{array}{l}\text { Number of individuals with } \\
\text { university/college degree, } \\
\text { thousand }\end{array}$} & \multirow[t]{2}{*}{ Increase, $\%$} & \multicolumn{2}{|c|}{$\begin{array}{l}\text { Rate of individuals with } \\
\text { university/college degree in } \\
\text { the total population, } \%\end{array}$} \\
\hline & 2001 & 2011 & & 2001 & 2011 \\
\hline Capital & 320.9 & 467.6 & 45.7 & 19.1 & 28.9 \\
\hline Town of county rights & 262.4 & 376.3 & 43.4 & 13.4 & 19.8 \\
\hline Other town & 232.6 & 372.8 & 60.3 & 7.8 & 12.7 \\
\hline Village & 118.1 & 222.9 & 88.7 & 4.1 & 7.9 \\
\hline Total & 934.1 & 1439.7 & 54.1 & 9.8 & 15.5 \\
\hline
\end{tabular}

Source: HCSO http://www.ksh.hu/nepszamlalas/tables_regional_00, Table 4.1.4.1.

The analysis of settlements data shows that there is a levelling process among the settlements throughout the periods considering the specific indices of education level. The change at lower education levels was significant between 1990 and 2001, while the increase in the rate of secondary and tertiary education characterises the period between 2001 and 2011. However, the concentration of the population with university/college degree is in larger towns, particularly in the capital and in towns of county rights, which is still prominent and corresponds to the international experience of the spatial concentration of knowledge-intensive activities.

\section{Highly educated individuals at subregional and county levels}

The indices of dissimilarity studied confirm the presence of a levelling process of educational attainment at settlement level over two decades. Nevertheless, it also needs to be considered that in the case of the population with university/college degrees, the place of living and the workplace is often separate, several urban regions are characterised by suburbanisation processes. Consequently, it is useful to analyse the statistical subregions (LAU 1), of which Hungary has 175, and the counties (there are 19 units of NUTS 3 level). The population of Budapest was 1,745,000 persons in 2013, the population of the second most populated subregion is much smaller (258,000 persons of Miskolc); due to the dominance of the capital in terms of settlement network, it is practical to analyse the indices with and without Budapest (Lengyel-Szakálné Kanó 2012). Teperics et al. (2016) found that the index based on the education level is in correspondence with the hierarchy of settlements owing to the differences in accessibility to public and higher educational institutions. Although we could study city-regions in this framework too, we were first interested in gaining a general picture on a subregional level.

Regional Statistics, Vol. 7. No. 2. 2017: 171-189; DOI: 10.15196/RS070209 
In the examined period, each territorial dissimilarity index decreased at the subregional level as well (see Table 4). The levelling process was more dynamic with Budapest included, than without the capital. In the case of highly educated individuals, the levelling process marginally accelerated after 2001.

Table 4

Three dissimilarity indices of highly educated individuals at subregional level

\begin{tabular}{l|c|c|c}
\hline \multicolumn{1}{c|}{ Dissimilarity index } & 1990 & 2001 & 2011 \\
\hline Calculated with data of Budapest & & & \\
Weighted coefficient of variation (\%) & 54 & 53 & 48 \\
Hoover index & 23 & 23 & 21 \\
Gini index & 0.30 & 0.29 & 0.27 \\
Calculated without data of Budapest & & & \\
Weighted coefficient of variation (\%) & 43 & 45 & 41 \\
Hoover index & 19 & 19 & 18 \\
Gini index & 0.24 & 0.25 & 0.23
\end{tabular}

Source: Own calculation.

Rate of highly educated individuals in the total population, by subregion, 2011

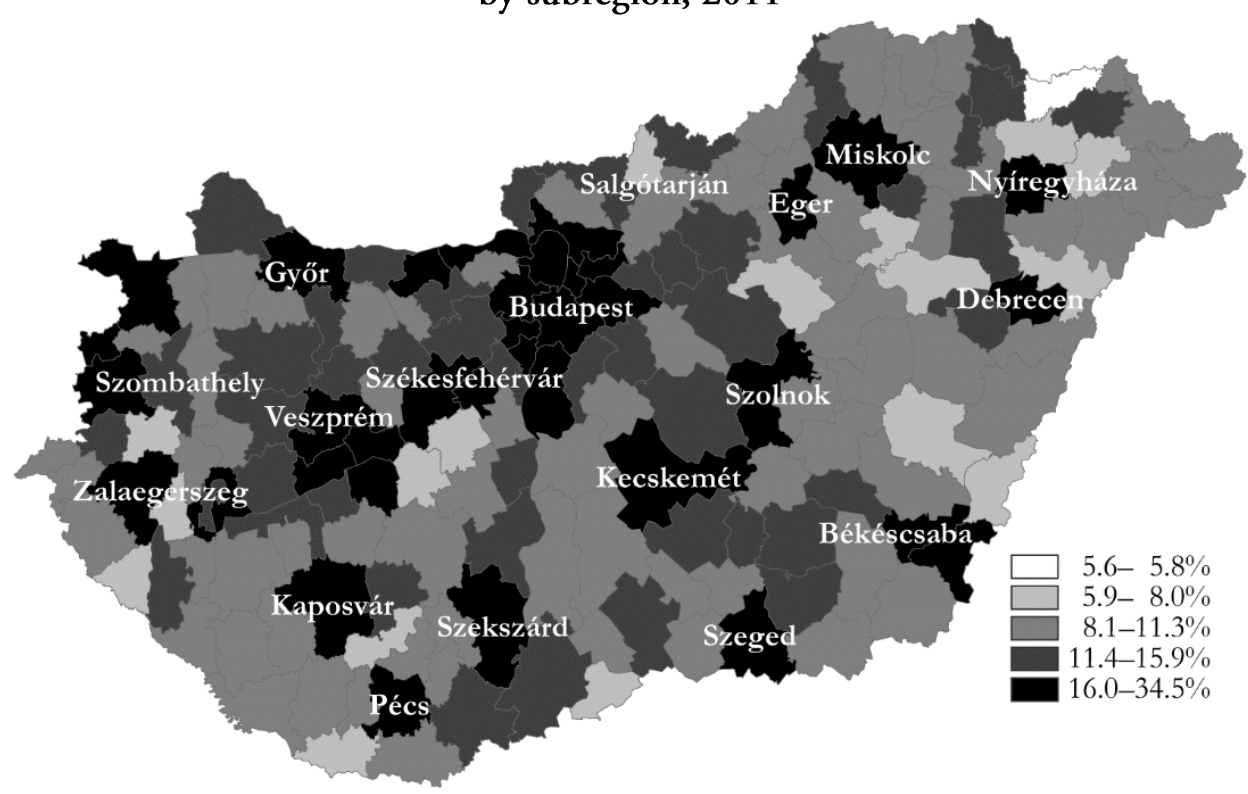

Source: Own elaboration based on HCSO census data. 
Apart from the capital (which we consider as a subregion), the rate of the population completing tertiary education was the highest in three subregions, Budaörs, Szentendre, and Pilisvörösvár (over 30\%) in 2011 (see Figure 5). It also shows a high rate of the subregions of larger provincial university towns (Szeged, Pécs, Debrecen, Eger, and Veszprém).

There is a very dynamic change between 2001 and 2011, where the values fluctuate on a scale of $2-10$ percentage points (see Figure 6 ). The rate of highly educated individuals increased by at least 10 percentage points in the agglomeration of the capital, where there is a high degree of concentration in the areas around Budapest. Thus, the extent of growth is most substantial in the agglomeration of Budapest and the larger provincial university towns, but they are not characterised by the highest rate of growth as the increase was over $60 \%$ in the case of 73 rural subregions. This latter phenomenon reflects the process towards levelling.

Figure 6

\section{Change in the rate of highly educated individuals in the total population,} by subregion, 2001-2011

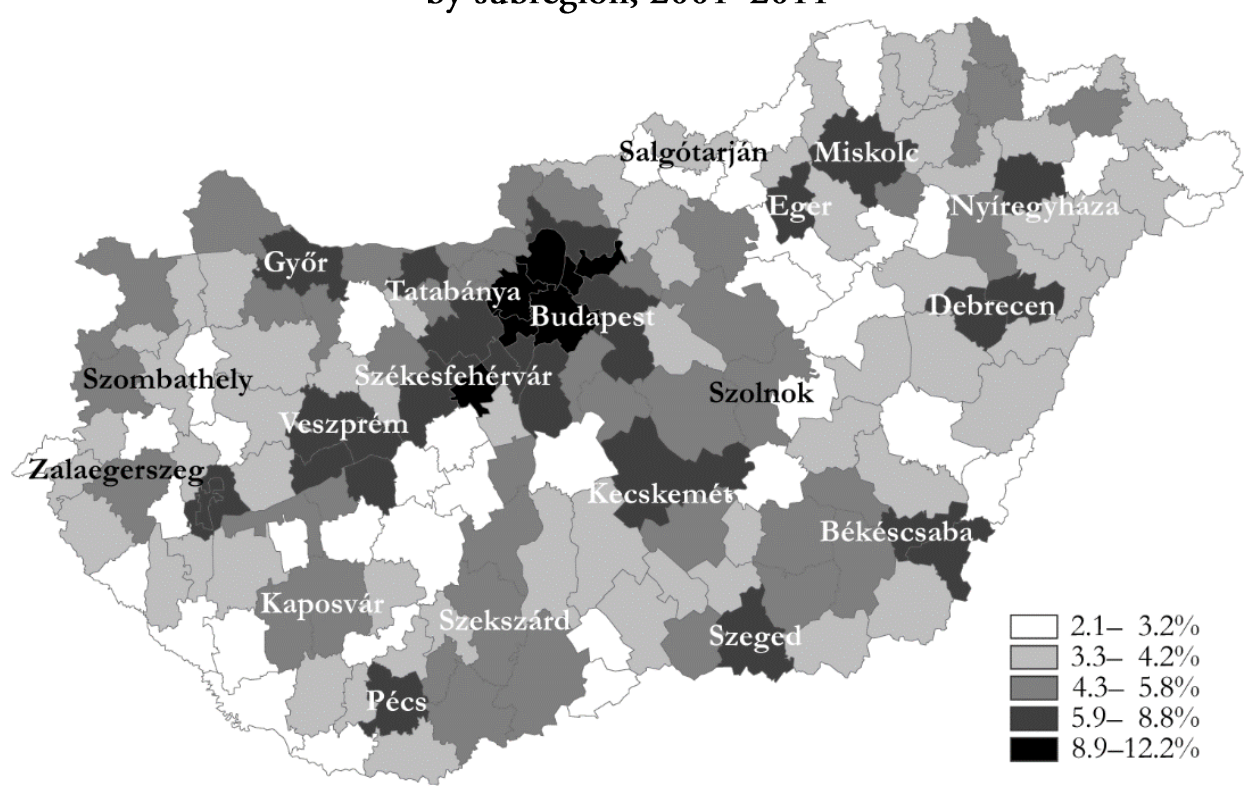

Source: Own elaboration based on HCSO census data.

The rate of highly educated individuals increased in each subregion between 2001 and 2011, but the rate of growth was generally higher in the subregions with a lower level of education (Hajdúhadháza, Mórahalom, Tét, etc.) than in those where the rate of highly educated individuals was originally higher (see Figure 7). Subregions with centres in the Budapest agglomeration (Gyál, Tét, Monor, Martonvásár,

Regional Statistics, Vol. 7. No. 2. 2017: 171-189; DOI: 10.15196/RS070209 
Veresegyház, Gödöllő, Érd, Dunakeszi, Pilisvörösvár, Szentendre, and Budaörs) also have higher growth rate of highly educated individuals, which suggests the presence of suburbanisation.

Figure 7

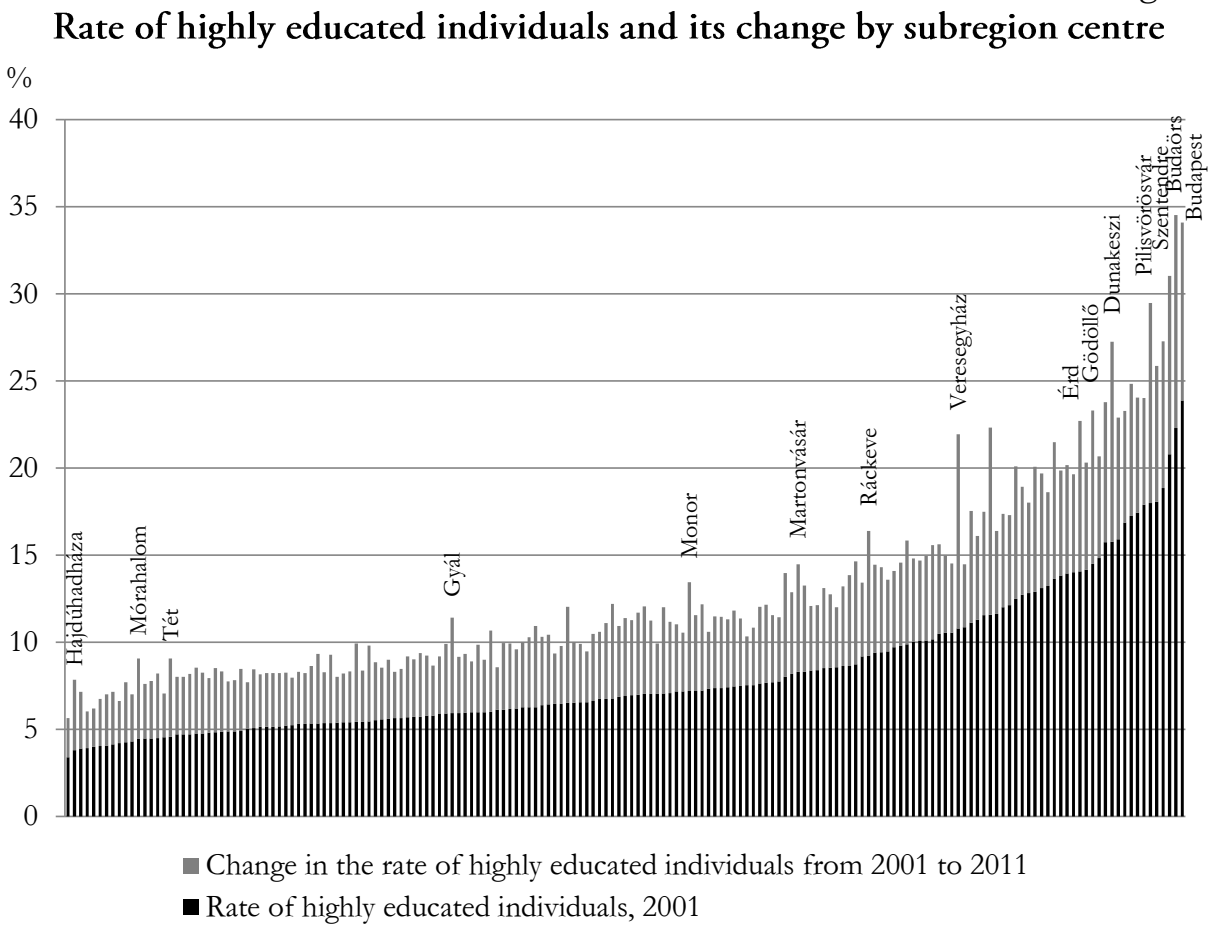

Note: The figure highlights only those subregion centres that were mentioned in the text. Source: Own elaboration.

We can write a logarithmic regression equation on the rate increase of highly educated individuals by subregion, which helps to verify $\beta$ convergence. In terms of the period of 2001-2011, the following regression equation describes the correlation with a good approximation:

$$
\begin{gathered}
\ln y_{2011}-\ln y_{2001}=0.1939-0.1012 \cdot \ln y_{2001}+u \\
R^{2}=0.2500 ; p_{\beta_{1}}=1.86 \cdot 10^{-12},
\end{gathered}
$$

where $u$ denotes the error term, $p$ indicates the significance level of $\beta_{1}$. The relationship indicates that the level of subregions is also characterised by a territorial levelling process. The coefficient of $\ln y_{2001}$ is significantly negative. In other words, in the case of the subregions with a lower rate of highly educated individuals in 2001, the examined index increased from 2001 to 2011 at a higher rate than in those subregions where the initial value was higher. The extent of growth would obviously 
show a reciprocal correlation: the extent of increase was the greatest in Budapest (considering the capital as a subregion, where the rate of $23.9 \%$ in 2001 increased to $34.1 \%$ in 2011, while it rose from 12.6 to $19 \%$ at the national level) and in the subregions of its agglomeration, which indicates a very dynamic spatial process.

As mentioned, agglomeration economies and the presence of a critical mass are of major importance in global competition (Capello 2015, McCann 2013). We categorise the subregions into five types on the basis of their population number (see Table 5). In the capital and in the subregions with a minimum of 100,000 inhabitants, the rate of highly educated individuals significantly exceeds the national average throughout the periods; it varies similarly to the average in the subregions with 50,000-99,000 persons, while it falls behind the average in the subregions with a lower number of inhabitants. In terms of the size of subregions, a certain process of levelling can be observed; mostly, the growth rate of the capital slowed down (due to the mentioned suburbanisation processes), while that of the other subregions was over the national average.

Table 5

Percentage and change in the number of highly educated individuals in the population over 25 by the size of subregions

\begin{tabular}{|c|c|c|c|c|c|c|}
\hline \multirow[t]{2}{*}{ Subregion size } & \multicolumn{3}{|c|}{$\begin{array}{c}\text { Rate of highly educated individuals in } \\
\text { the population over } 25, \%\end{array}$} & \multicolumn{3}{|c|}{ Change, $\%$} \\
\hline & 1990 & 2001 & 2011 & $2001 / 1990$ & $2011 / 2001$ & 2011/1990 \\
\hline Budapest & 19.1 & 23.9 & 34.1 & 16.7 & 46.3 & 70.9 \\
\hline $\begin{array}{l}\text { Population of } 100 \text { thou- } \\
\text { sand or more }\end{array}$ & 11.6 & 14.6 & 21.4 & 37.6 & 59.0 & 118.8 \\
\hline $\begin{array}{l}\text { Population of } 50-99 \\
\text { thousand }\end{array}$ & 8.3 & 11.0 & 16.9 & 42.7 & 61.3 & 130.2 \\
\hline $\begin{array}{l}\text { Population of } 20-49 \\
\text { thousand }\end{array}$ & 5.7 & 7.1 & 11.4 & 29.7 & 61.8 & 109.9 \\
\hline $\begin{array}{l}\text { Population of } 19 \text { thou- } \\
\text { sand or less }\end{array}$ & 4.3 & 5.6 & 9.2 & 31.3 & 60.7 & 110.9 \\
\hline Total & 10.1 & 12.6 & 19.0 & 29.2 & 55.6 & 101.0 \\
\hline
\end{tabular}

Note. The subregions were categorised by their 2011 population.

Source: Own calculation.

The decrease in the differences related to education level characterises not only the settlement and subregional data, but there is a certain levelling process among the counties as well (see Table 6). The value of the Gini index calculated on highly educated individuals decreased at each territorial level; the smallest dissimilarity is found among the counties, while the differences are rather bigger in the case of subregions and settlements. Evidently, the institutions of local public administration, and the organisations of higher education, health care, and various public ser-

Regional Statistics, Vol. 7. No. 2. 2017: 171-189; DOI: 10.15196/RS070209 
vices are concentrated in larger towns, county seats in particular, and provide for the entire population of the county.

Table 6

Gini index based on the rate of highly educated individuals in the total population and its change by territorial level

\begin{tabular}{|c|c|c|c|c|c|}
\hline \multirow{2}{*}{ Territorial level } & \multicolumn{3}{|c|}{$\begin{array}{c}\text { Rate of highly educated individuals } \\
\text { in the total population, } \%\end{array}$} & \multirow{2}{*}{$\begin{array}{c}\text { Change } 2001 / 1990, \\
\%\end{array}$} & \multirow{2}{*}{$\begin{array}{c}\text { Change } 2011 / 2001 \text {, } \\
\%\end{array}$} \\
\hline & 1990 & 2001 & 2011 & & \\
\hline Settlement & 0.38 & 0.37 & 0.33 & -3 & -11 \\
\hline Subregion & 0.30 & 0.29 & 0.27 & -1 & -9 \\
\hline County & 0.21 & 0.20 & 0.19 & -4 & -5 \\
\hline
\end{tabular}

Source: Own calculation.

One explanation for territorial levelling may be the significant expansion of higher education after 1990, and the popularity of correspondence courses and adult education. Prior to 1990, 8-10\% of the given age groups studied in higher education and there was no demand for university graduates in the socialist planned economy. With the transition to a market economy, not only the young people entered higher education in large numbers, but the employers also expected their workers to train themselves, for instance, in the public sector. The number of people with tertiary level qualifications was an annual average of 24,000 at the beginning of the 1990s, which gradually increased and reached 57,000 by 2005 ; since then it has marginally decreased and it is approximately 50,000-53,000 persons per year. The number of people with a degree in adult education increased dynamically from 1995, in the period 2003-2008, over 20,000 persons per year acquired tertiary level qualifications, which decreased to 10,000-15,000 from 2009. The demands for higher education in correspondence and distance learning were generated mainly by the labour market requirements towards rural employees with no degrees (e.g. public employees). In our opinion, it had a major role in territorial levelling that a large number of degrees could be gained in settlements far from higher educational institutions alongside job commitments, while the people completing full-time training work mostly in larger towns, particularly in Budapest.

\section{Conclusions}

Our research aimed to analyse the education level of the population and its territorial changes in Hungary over the period of 1990-2011. Our study particularly focused on highly-qualified labour force, highly educated individuals, as qualified human resources have major importance in a knowledge-based economy (Gál 2010, Pike et 
al. 2006, Stimson et al. 2011). We used statistical methods widely applied in regional sciences to analyse territorial processes and differences.

In Hungary, the number and rate of educated people continuously increased from 1990. More specifically, the rate of the population with secondary and tertiary qualifications showed a substantial growth. The analysis of the data revealed that not only the rate of educated people increased in a particular age group at the national level, but simultaneously, there was a slow territorial levelling process at each studied territorial level: at the level of settlements, subregions, and counties.

The literature of regional science suggested that the population with university/college degree is concentrated in larger towns and it leads to an increase in territorial differences; thus, we find it surprising that the rate of the population with degrees increased everywhere, even in less advanced regions, and it led to a decrease in territorial dissimilarities. Its profound explanation requires further research; we assume that territorial levelling can be partially explained by the fact that the number of people with degrees employed in the public sector increased in less advanced regions as well, owing to further training in several cases. In the small towns of less developed regions, a reindustrialisation process generated by foreign direct investments started after 2004, accompanied by related business services, which require a labour force with knowledge in foreign languages and university degree. Completed tertiary education is also becoming increasingly important for agricultural enterprises operating in the settlements of rural regions. While suburbanisation earlier emerged primarily in the agglomeration of the capital, subsequent to 2000 , it developed in the majority of the 23 towns of county rights; a part of the population that moved to the smaller settlements in the surrounding area have completed tertiary education. Another factor facilitating levelling is that higher educational institutions were also established in smaller provincial towns from the mid-1990s.

The changes occurring over the two decades studied prognosticate the expected future tendencies: we assume that the territorial levelling process of the population completing secondary school continues, although at a slower pace, while the territorial levelling of the rate of highly educated individuals is expected to stop and urban concentration processes will intensify. In our opinion, it is already reflected by the decreasing number of certificates gained in correspondence courses over the last years.

\section{REFERENCES}

BARTA, GY.-G. FekETE, É.-SzÖRÉnYiné KukOrelli, I.-TimÁr, J. (eds.) (2005): Hungarian Spaces and Places: Patterns of Transition Centre for Regional Studies of HAS, Pécs.

BenOS, N.-ZOTOU, S. (2014): Education and economic growth: a meta-regression analysis, World Development 64: 669-689.

Regional Statistics, Vol. 7. No. 2. 2017: 171-189; DOI: 10.15196/RS070209 
Brandmueller, T.- Schäfer, G.- EkKehard, P.- Müller, O.- Angelova-Tosheva, V. (2017): Territorial indicators for policy purposes: NUTS regions and beyond, Regional Statistics 7 (1): 78-89. https://doi.org/10.15196/RS07105

CAPELlO, R. (2015): Regional Economics Routledge, London-New York.

Dicken, P. (2015): Global Shift. Mapping the Changing Contours of the World Economy ( $7^{\text {th }}$ ed.). The Guilford Press, New York.

DudÁs, G.-VIDA, GY. -KOVAlcsiK, T. -BOROS, L. (2017): A socio-economic analysis of Airbnb in New York City, Regional Statistics 7 (1): 135-151. https://doi.org/10.15196/RS07108

DuseK, T.-Kotosz, B. (2016): Területi statisztika Akadémiai Kiadó, Budapest.

DuseK, T.-LuKÁCS, R.-RÁCZ, I. (2014): Development Differences Among the Regions of Hungary Procedia Economics and Finance 9: 264-277. https://doi.org/ 10.1016/S2212-5671(14)00028-8

Fischer, M. M.-Getis, A. (eds.) (2010): Handbook of Applied Spatial Analysis: Software Tools, Methods and Applications Springer-Verlag, Heidelberg.

FisCHER, M. M.-NiJKAMP, P. (eds.) (2014): Handbook of Regional Science Springer-Verlag, Berlin-Heidelberg.

GÁL, Z. (2010): The role of research universities in regional innovation: The case of South Transdanubia, Hungary In: Longworth, N.-Osborne, M. (eds.) Perspectives of Learning Cities and Regions pp. 84-105., National Institute of Adult Continuing Education, Leicester.

Gál, Z. 2016: Egyetem és a város Educatio 25 (2): 220-233.

HCSO (2011): Personal questionnaire. Hungarian Central Statistical Office, Budapest. http://www.ksh.hu/nepszamlalas/docs/kerdoivek/szemely_angol.pdf

HCSO (1993): 1990. évi népszámlálás. CD-ROM

HCSO (2003): Népszámlálás 2001, 6. Területi adatok. http://www.nepszamlalas2001.hu / hun/kotetek/06/index.html (downloaded: 20 ${ }^{\text {th }}$ April 2015)

HCSO (2013): 2011. évi népszámlálás, Területi adatok http://www.ksh.hu/nepszamlalas/ tablak_teruleti_00 - http://www.ksh.hu/nepszamlalas/tablak_teruleti_20 (downloaded 12th March 2015)

KINCSES, Á. (2015): International migration diversity in Hungary in the 2011 Population Census data, Regional Statistics 5 (2): 108-124. https://doi.org/ 10.15196/TS05206

KISS, J. P.-TAGAI, G.-TELBISZ, E. (2008): A szürkeállomány területi különbségei - katedrán innen és túl Területi Statisztika 48 (3): 315-333.

KOZMA, T.-TőZsÉR, Z. 2016: Education and Transition in Hungary: Policy and Research in the Process of Transformation, 1988-2004 Hungarian Educational Research Journal 6 (2): 23-42. https:/ / doi.org/10.14413/HERJ.2016.02.03

LENGYEL, B.-LEYDESDORFF, L. (2011): Regional innovation systems in Hungary: the failing synergy at the national level Regional Studies 45 (5): 677-693. https://doi.org/10.1080/00343401003614274

LENGYEL, I. (2004): The pyramid model: enhancing regional competitiveness in Hungary Acta Oeconomica 54 (3): 323-342. https://doi.org/10.1556/AOecon. 54.2004.3.3

Regional Statistics, Vol. 7. No. 2. 2017: 171-189; DOI: 10.15196/RS070209 
LENGYEL, I.-SZAKÁLNÉ KANÓ, I. (2012): Competitiveness of Hungarian urban microregions: localization agglomeration economies and regional competitiveness function Regional Statistics 52 (2): 27-44. https://doi.org/10.15196/RS02103

MCCANN, P. (2013): Modern urban and regional economics (2 ${ }^{\text {nd }}$ ed.). Oxford University Press, Oxford.

Nemes Nagy, J. (2005) (ed): Regionális elemzési módszerek Regionális Tudományi Tanulmányok, 11. ELTE Regionális Földrajzi Tanszék - MTA-ELTE Regionális Tudományi Kutatócsoport, Budapest.

Nemes Nagy, J. (2009): Terek, helyek, régiók. A regionális tudomány alapjai Akadémiai Kiadó, Budapest.

Pike, A.-Rodrígues-Pose, A.-Tomaney, J. (2006): Local and regional development Routledge, London-New York.

RECHNITZER, J.-SMAHÓ, M. (2006): Regional Characteristics of Human Resources in Hungary during the Transition Discussion Papers, No 50., Centre for Regional Studies of HAS, Pécs.

SÁNTA, É.-SZAKÁLNÉ KANÓ, I.-LENGYEL, I. (2015): Csökkennek az iskolázottság területi egyenlőtlenségei? A felsőfokú végzettségűek területi eloszlása a népszámlálások adatai alapján Területi Statisztika 55 (6): 518-540.

RÓBERT, P. (1991): Educational Transition in Hungary from the Post-War Period to the End of the 1980s. European Sociological Review 7 (3): 213-236. https://doi.org/10.1093/oxfordjournals.esr.a036602

Stimson, R.-STOUGH, R. R.-NijkAMP, P. (2011): Endogenous regional development, Edward Elgar, Cheltenham.

Teperics, K. (2016): The Territorial Characteristics of the Four Pillars In: KozMA, T. (ed.) Learning regions in Hungary from theory to reality pp. 107-135., Tribun EU, Brno.

TEPERICS, K.-SZILÁGYINÉ CZIMre, K.-MÁRTON, S. (2016): A tanuló városok és régiók területi megjelenése és társadalmi gazdasági mutatókkal való kapcsolata Magyarországon Educatio 25 (2): 245-259

Timár, J. (2007): Different Scales of Uneven Development - in a (No Longer) Post-socialist Hungary Treballs de la Societat Catalana de Geografia 64: 103-128.

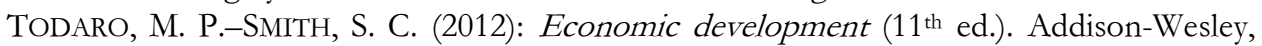
Harlow.

Regional Statistics, Vol. 7. No. 2. 2017: 171-189; DOI: 10.15196/RS070209 